\title{
Determining Groundwater Potential Using Vertical Electrical Sounding Method In Manggar, Balikpapan City, Indonesia.
}

\author{
Febrian Dedi Sastrawan ${ }^{1, *}$, Rahmania $^{1}$, Meidi Arisalwadi ${ }^{1}$

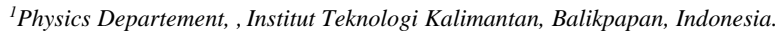

* Corresponding author : Febrian.dedi@lecturer.itk.ac.id

Tel.: +62-853-4111-2790

Received:Aug 17, 2020. ; Accepted: Dec 22, 2020.

DOI 10.25299/jgeet.2020.5.4.5495

\begin{abstract}
Clean water requirement in Manggar Urban Village of Balikpapan City is rising along with population growth. The main source of clean water that can be used is ground water in the aquifer layer. The Study of groundwater potential was conducted using vertical electrical sounding (VES) method to determine the presence and types of aquifer layers. The measurements along four measurement points revealed four aquifers buried in depth ranging from 48 to $53 \mathrm{~m}$ below the surface. The layer which is potential to be an aquifer is a sand layer with moderate-sized grain. The resistivity values for sand layer at each measurement point vary from 221 to $281 \Omega \mathrm{m}$. The estimation of sand to be an aquifer layer was supported by the calculation of formation factors. The calculation was based on the ratio of resistivity values from pore-filling water and resistivity values from water-saturated rocks layer. The aquifer revealed in this study is categorized as unconfined aquifer because the upper layer is restricted by sandy clay. The resistivity values vary from 12.8 to $35.4 \Omega \mathrm{m}$ which behaved as an aquitard layer. However, low resistivity values between 9.6 to $20 \Omega \mathrm{m}$ are detected under the aquifer layer. The layer is identified as clay which behaved as an impermeable layer or aquiclude.
\end{abstract}

Keywords: Groundwater, Resistivity, Aquifer, factor formation.

\section{Introduction}

Manggar is one of the Urban Villages in Balikpapan City which is now growing rapidly. Manggar becomes one of the centers of heavy equipment and oil and gas industry. This situation also lead the rising of clean water needs in this area. Besides that, long dry season occurs in Balikpapan City, including Manggar area often triggers a clean water crisis (Sulistyo and Abrar, 2017).

Clean water is an important aspect of human life (Hadian et al., 2017). The requirements of clean water over time are becoming increasingly as the population gets bigger in the area. To suit water needs increasingly, the availability of clean water sources needs to be preserved. One source of clean water that can be utilized is ground water. Ground water is water present beneath earth's surfaces that fills the rock pores or soil layers (Sihotang et al., 2018; Suryadi et al., 2018).

The One of more effective ways useful to find groundwater sources is to run Geophysical survey in order to understand subsurface conditions. The geophysical method that can be used to determine the presence of groundwater sources is Geoelectrical method of Vertical Electrical Sounding (VES) (Mohamaden, 2016; Mohamed, 2016). VES is one type of the most important method that can be used in the field of groundwater study (Abd El-Gawad et al., 2017). Geoelectrical method of VES reveals resistivity profiles and rock layer thickness of subsurface (Sathiyamoorthy and Ganesan, 2018). The rock layers have been water saturated will produce resistivity anomalies when compared to the layers have not been saturated. The resistivity anomalies obtained can be used to determine the presence of groundwater sources (Mohamaden, 2016). The Geoelectrical is a wonderful and effective method used for mapping of shallow and moderate subsurface conditions, therefore this method is suitable to run in groundwater surveys (Alfadli and Natasia, 2017). Numerous authors have conducted a research about the existence of groundwater sources using Geoelectrical methods (Aizebeokhai et al., 2017; Kayode et al., 2016; Mohamaden and Ehab, 2017).

\section{Research Area Setting}

The measurement points located at Manggar Urban Village of Balikpapan City (Fig. 1). The topographical condition at the measurement points is relatively flats and dominated by red Podsolic soil. Red Podsolic soil is very sticky when exposed to rain and very dry during the long dry season. Geologically, the rock formations found in the study area are included in Alluvium deposits. Alluvium deposition is estimated generated in Holocene age which is originated from river, swamp, beach and delta deposits consisting of Gravel, Sand, Sandstone, and Mud.

One of a large River in the study area is Manggar river controlling the high level of erosion and sedimentation in that area. The Manggar River also affects hydrology of the area because it is directly connected to the Manggar coast. This fact directly lead to the rising of groundwater pollution due to sea water.

Groundwater basin in Balikpapan City is formed by Alluvium deposits with the flow system through rock porosity or space between grains of rock layers. Based on the research conducted by Geological Agency, there are several types of aquifers, namely unconfined aquifer and confined aquifer. The unconfined aquifer is associated with shallow depth groundwater sources ranging from $1 \mathrm{~m}$ to $5 \mathrm{~m}$ and medium depth ranging from 40 to 50 meters. While confined aquifer is associated with deep groundwater sources. 


\section{Method}

Survey of VES method was carried out at four measurement points where the length of each measuring point is $200 \mathrm{~m}$. The basic principle of VES method is an electric current injected below the earth's surface through two electrodes with certain distance and potential difference appearing between the two electrodes. The measurement of VES method used Schlumberger configuration electrode array
(Fig. 2). The electrode array consisted of two current electrodes and two potential electrodes connected to the Naniura NRD 300 resistivity meter. The magnitude of the injected current and the distance between the electrodes are factors affecting of penetration depth. Vertical subsurface conditions can be obtained by making variations of the current electrode spacing during field measurement activities.

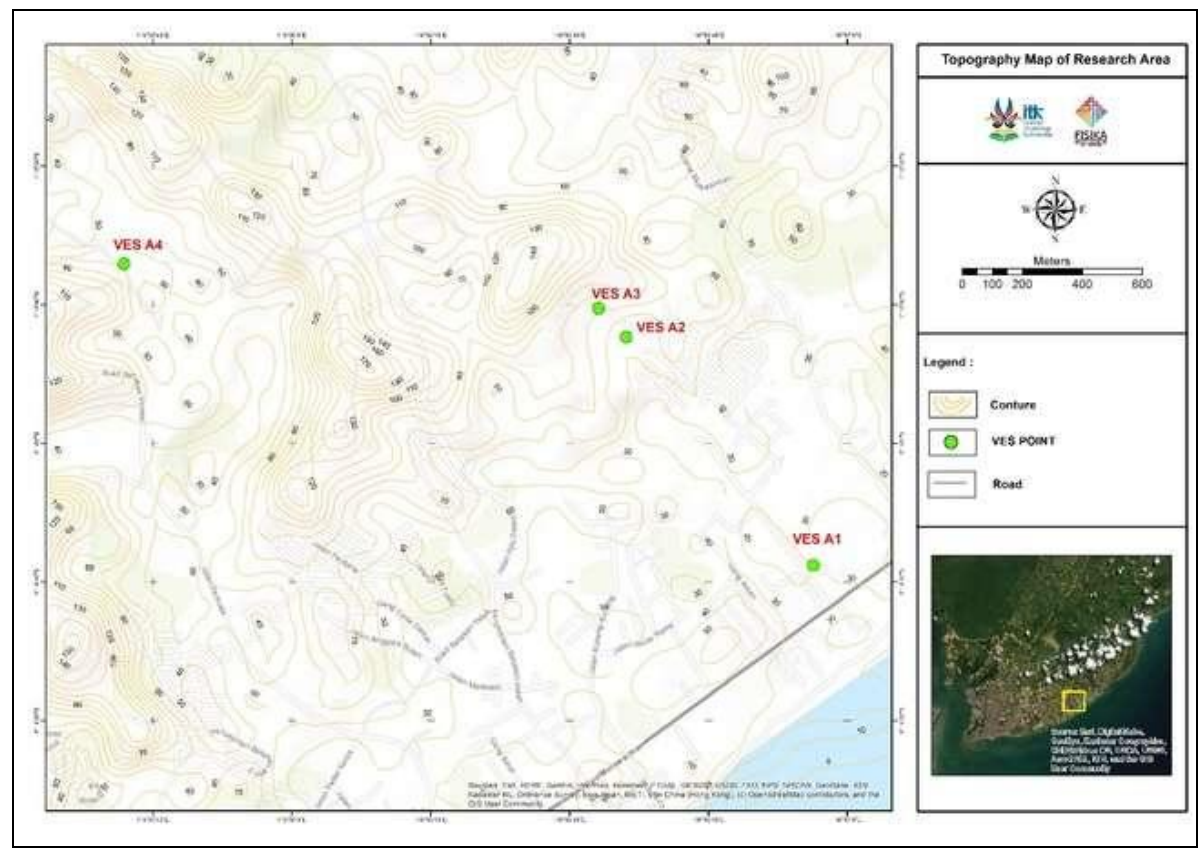

Fig. 1. Contour map of study area and the location of Vertical electrical sounding (VES) method applied in groundwater survey.

Data obtained in this measurement are the magnitude of injected current (I) and the magnitude of the potential difference generated (V). The data collected from each measurement point are used to obtain the apparent resistivity values of the subsurface layers by using geometrical factor $(\mathrm{k})$ of the Schlumberger configuration. The equation of geometry factor (k) is expressed by (Loke, 1999):

$$
k=\pi \frac{\left(L^{2}-I^{2}\right)}{2 l}
$$

The apparent resistivity values $(\rho a)$ of subsurface are obtained by using the equation :

$$
\rho_{a}=k \frac{V}{I}
$$

The rock resistivity values of water saturated will be proportional to the water resistivity values filled-pore (Dahlan et al., 2016: Arif et al., 2015). Based on this relation, a formation factor $(\mathrm{F})$ value is yielded in describing rock porosity.

The values can be used to determine the existence of aquifer layers below the surface. The formation factor equation is the ratio between rock resistivity $(\rho)$ and resistivity values of water filled-pores $(\rho \mathrm{a})$.

$$
F=\frac{\rho}{\rho_{a}}
$$

The results of hydrogeological studies are relation between rock resistivity and water resistivity of filled-pores that can be presented in table 1 (Taib., 1990). The resistivity values of water filled-pores are obtained by measuring directly from residents' wellsusing a portable conductivity meter (Fig. 3).

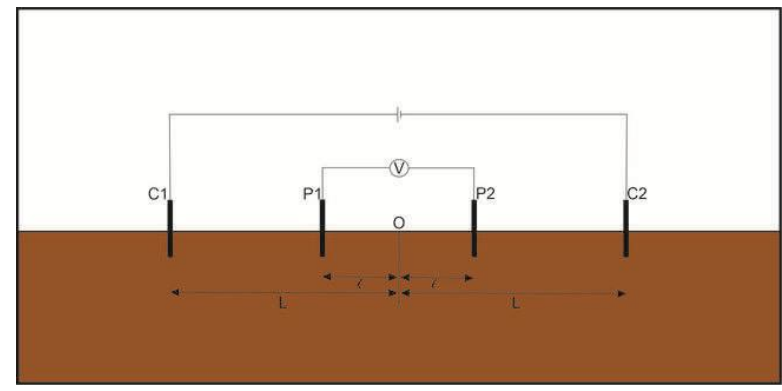

Fig. 2. Electrode array of Schlumberger configurations for resistivity measurements

\begin{tabular}{|c|c|c|}
\hline$(F)$ & Formation & layer \\
\hline$\leq 1$ & Clay & Aquiclude \\
\hline $1-1.5$ & $\begin{array}{l}\text { Peat, Clayed sand } \\
\text { atau silf }\end{array}$ & Aquiclude \\
\hline 2 & Silf- find sand & Poor to medium aquifer \\
\hline 3 & Medium sand & $\begin{array}{l}\text { Medium to Productive } \\
\text { aquifer }\end{array}$ \\
\hline 4 & Coarse sand & Productive aquifer \\
\hline 5 & Gravel & HiglyProductive aquifer \\
\hline
\end{tabular}

Table 1. The Classificationof Formation Factors in Sedimentary Rock

When we conducted field measurement, data obtained have to present good quality data. Good quality data are obtained by performing measurement Quality Control (QC). QC datais performed by logarithmic curves a $1 / 2$ of currents electrode spacing versus apparent resistivity values of measurement data (Fig. 4) 


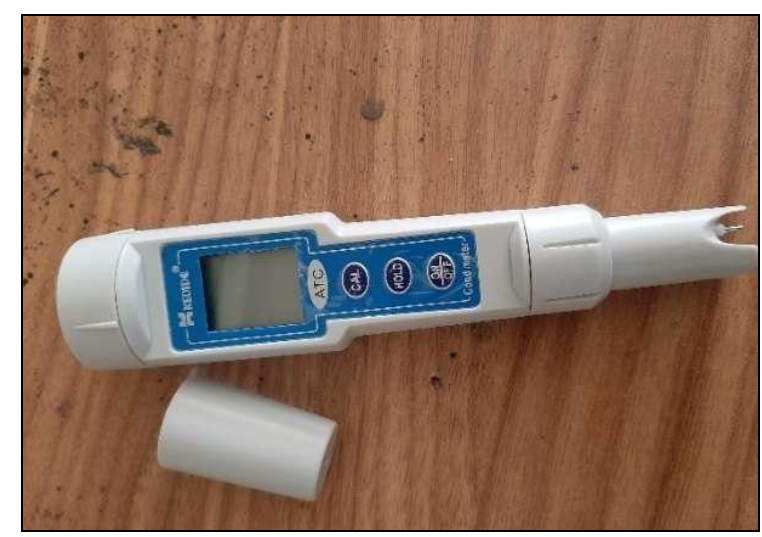

Fig. 3. Conductivity meter

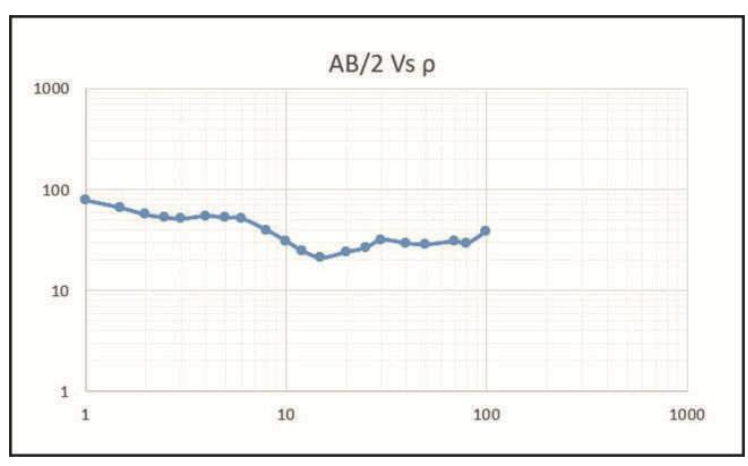

Fig. 4. Curve current electrode spacing $(1 / 2 \mathrm{AB})$ in meters vs

Apparent resistivity ( $\rho \_a$ ) in $\Omega \mathrm{m}$ drawn in logarithmic scale.

\section{Result And Discussion}

The measurement points were located in settlements beginning to be densely-populated (Fig. 6). Based on the resistivity values from four subsurface 1-D resistivity model and the formation factor were obtained, thus the types of subsurface layers and the existence of aquifer layer can be identified. The average resistivity ( $\rho$ a) value of water filledpores is $74 \Omega \mathrm{m}$. This value will be used to determine the types of subsurface layers (Fig. 6).

\subsection{1-D Resistivity Model for VES A1}

The Results of data processing from measurement point VES A1 were identified 1-D resistivity model consisting 4 subsurface layers indicated by variations of rock resistivity values. Penetration depth can be obtained at measurement point VES A1 around $85 \mathrm{~m}$ from the surface. The first layer with resistivity value $36.8 \Omega \mathrm{m}$ is identifiedas overburden. The second layer with resistivity value $26.3 \Omega \mathrm{m}$ is identified as sandy clay layer. This layer is aquitard layer found in depth range from 1.9 to $51 \mathrm{~m}$ beneath the surface. The third layer with resistivity value $228 \Omega \mathrm{m}$ and formation factor value 3 is identified as medium grain sized- sand behaved to be potential aquifer layer buried in depth 51 to $85 \mathrm{~m}$. This layer is characterized as an unconfined aquifer layer. However, low resistivity value $20 \Omega \mathrm{m}$ appears at Fourth layer in depth up to $85 \mathrm{~m}$ isinterpreted as clay and behave as impermeable layer or aquiclude.

\subsection{1-D Resistivity Model for VES A2}

The data processing results at VES A2 are identified 5 layers by resistivity values varied between 9.68 to $221 \Omega \mathrm{m}$. The first layer is overburden, then the second layer is estimated to be free aquifer layer which is located indepth range from 1.6 to $3 \mathrm{~m}$ below the surface. This layer with resistivity value of $188 \Omega \mathrm{m}$ and the formation factor value of 2.5 obtained from the data calculation indicating this layer is a fine sand layer. The third layer is sandy clay or aquitard layer with a resistivity value of $28.7 \Omega \mathrm{m}$. The fourth layer is an aquifer layer with reactivity value of $221 \Omega \mathrm{m}$ and formation factor value of 3 . This layer is estimated as medium grain sized-sand that can store and transmit water buried in depth range from 52 to $82 \mathrm{~m}$ from the surface. This aquifer layer is characterized as unconfined aquifer layer. The low resistivity value of $9,68 \Omega \mathrm{m}$ at the last layer is interpreted as clay and behave as an aquiclude layer.

\subsection{1-D Resistivity Model for VES A3}

The results of measurement point at VES A3 are identified 4 subsurface layer with penetrations depth of up to $88 \mathrm{~m}$. The subsurface resistivity value from the result of data processing varies from 13 to $254 \Omega \mathrm{m}$. The first layer is overburden with thickness around $1 \mathrm{~m}$. The second layer with a resistivity value of $35.4 \Omega \mathrm{m}$ and located in depth range from 1 to $48 \mathrm{~m}$ is interpreted as an aquitard layer, namely sandy clay layer. The third layer is estimated to be a unconfined aquifer layer with resistivity value of $245 \Omega \mathrm{m}$ and formation factor valueof 3.4. This layer is estimated as medium grain sized-sand located in depth range from 48 to $88 \mathrm{~m}$ below the surface. While, low resistivity value appearing beneath sand layer is interpreted as clay which is buried in depth up to $88 \mathrm{~m}$ and behaveas impermeable layer or aquiclude.

\subsection{1-D Resistivity Model for VES A4}

1-D resistivity model of measurement point VES A4 is identified 5 subsurface resistivity layers. The first layer is overburden with thickness around $1 \mathrm{~m}$. The second layer with thickness $2 \mathrm{~m}$ has resistivity value $145 \Omega \mathrm{m}$ interpreted as fine sand and behaved as a free aquifer layer. The third layer with a resistivity value is $12.8 \Omega \mathrm{m}$ interpreted as sandy clay layer buried at depth ranges between 3 to $53 \mathrm{~m}$ below the surface and behaved as aquitard layer. The fourth layer is estimated as a free aquifer layer atdepth ranges from 53 to $95 \mathrm{~m}$. This layer has a resistivity value $281 \Omega \mathrm{m}$ and formation factor value 3 interpreted as medium grain sized-sand. The fifth layer is clay with resistivity value $10.1 \Omega \mathrm{m}$ and behaved as an aquiclude layer.

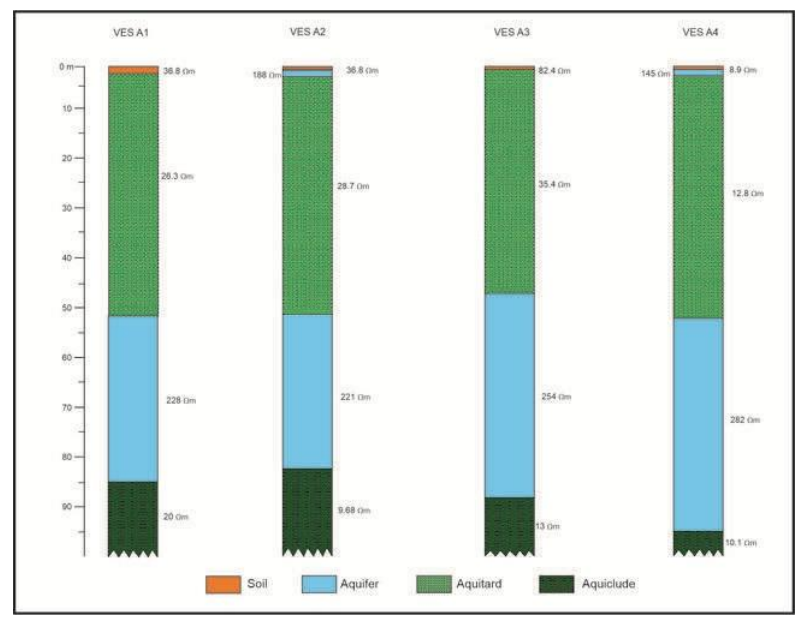

Fig. 5. Subsurface 1-D resistivity model 


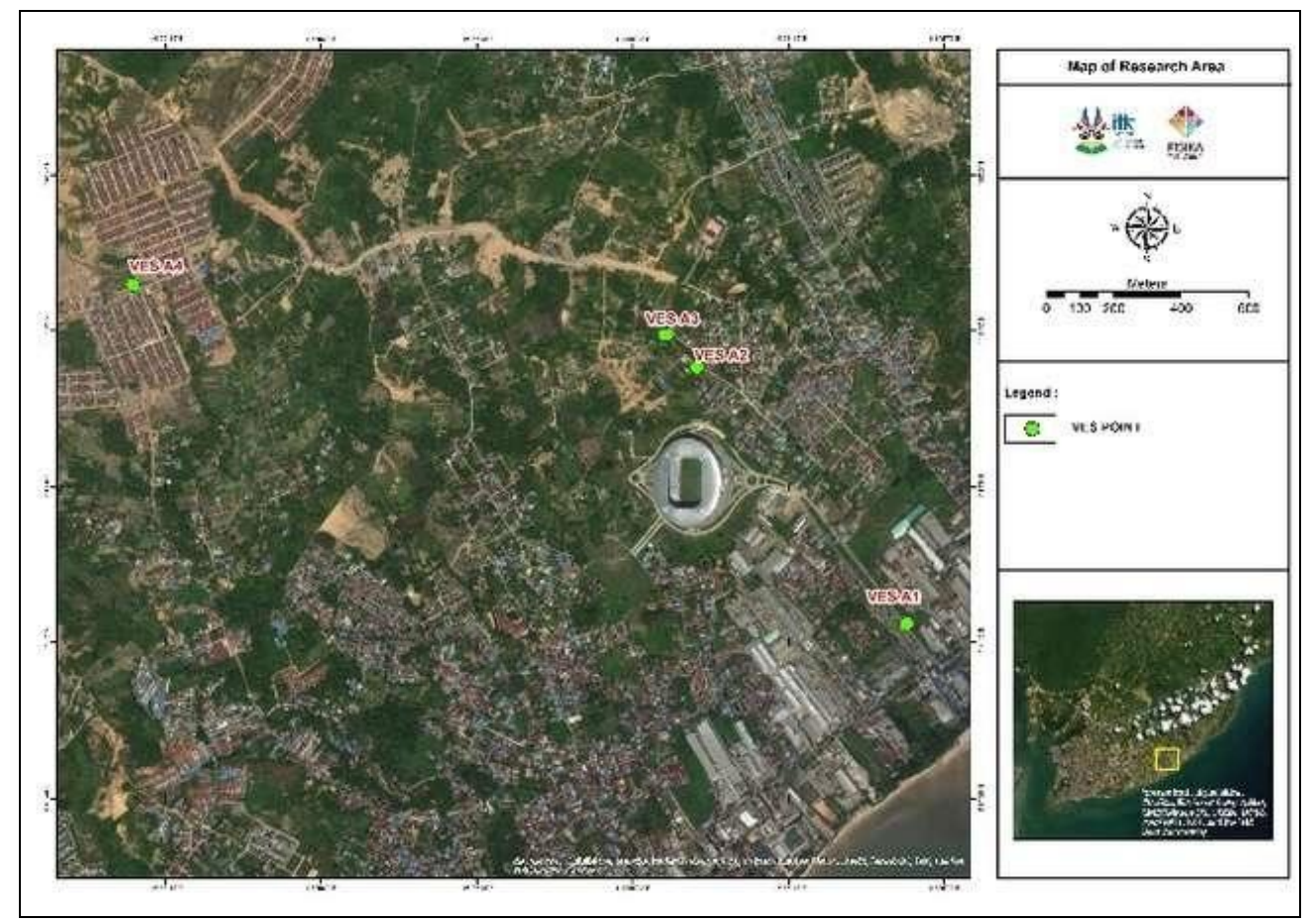

Fig. 6. Map of Research Area

\section{Conclusion}

Geoelectrical method of Vertical electrical sounding (VES) is effectively used in groundwater exploration. Based on the data analysis known that high resistivity values associated with aquifer layers. This result is supported by the calculation of formation factors obtained at each measurement point. The Layer with high resistivity values varies from 221 to $281 \Omega \mathrm{m}$ and formation factor values variesfrom 2 to 3 behaved as an aquifer layer. This layer is interpreted as medium grain sized-sand with the thickness estimation around $30 \mathrm{~m}$. Shallow aquifer layer at point VES A2 and VES A4 is located near the surface and buried in depth from 1 to $3 \mathrm{~m}$. The aquifer layers are obtained then classified as unconfined aquifer layer which is restricted by clay layer detected under the aquifer layer with low resistivity values from 9.68 to20 $\Omega \mathrm{m}$. This study shows that the aquifer layers In Manggar Urban Village of Balikpapan City are classified as medium to productive aquifer.

\section{Acknowledgements}

The authors would like to express many thanks to Ministry of Research and Technology/ National Agency for Research and Innovation for providing Research funding through the LPPM of Institut Teknologi Kalimantan by PDP Scheme. The authors also say many thanks to the Physics Students of Institut Teknologi Kalimanta involved in measurement field activities.

\section{References}

Abd El-Gawad, A.M.S., Kotb, A.D.M., Hussien, G.H.G., 2017. Geoelectrical contribution for delineation the groundwater potential and subsurface structures on Tushka Area, Egypt. NRIAG J. Astron. Geophys. 6, 379-394. https://doi.org/10.1016/j.nrjag.2017.10.003

Aizebeokhai, A.P., Oyeyemi, K.D., Noiki, F.R., Etete, B.I., Arere, A.U.E., Eyo, U.J., Ogbuehi, V.C., 2017. Geoelectrical resistivity data sets for subsurface characterisation and aquifer delineation in Iyesi, southwestern Nigeria. Data Br. 15, 828-832. https://doi.org/10.1016/j.dib.2017.10.057

Alfadli, M.K., Natasia, N., 2017. Geoelectricity Data Analysis For Identification The Aquifer Configuration In Bandorasawetan, Cilimus, Kuningan, West Java Province. J. Geosci. Eng. Environ. Technol. 2, 278. https://doi.org/10.24273/jgeet.2017.2.4.779

Hadian, M.S.D., Waliana, T.Y., Sulaksana, N., Putra, D.B.E., Yuskar, Y., 2017. Hydrochemistry and Characteristics of Groundwater: Case Study Water Contamination at Citarum River Upstream. J. Geosci. Eng. Environ. Technol. 2 ,

268. https://doi.org/10.24273/jgeet.2017.2.4.578

Kayode, J.S., Adelusi, A.O., Nawawi, M.N.M., Bawallah, M., Olowolafe, T.S., 2016. Geo-electrical investigation of near surface conductive structures suitable for groundwater accumulation in a resistive crystalline basement environment: A case study of Isuada, southwestern Nigeria. J. African Earth Sci. 119, 289302. https://doi.org/10.1016/j.jafrearsci.2016.04.009

Loke, D.M., 1999. Electrical imaging surveys for environmental and engineering studies. Cangkat Minden Lorong 6574525, 63.

Mohamaden, M.I.I., 2016. Delineating groundwater aquifer and subsurface structures by using geoelectrical data: Case study (Dakhla Oasis, Egypt). NRIAG J. Astron. Geophys. 5, 247-253. https://doi.org/10.1016/j.nrjag.2016.05.001

Mohamaden, M.I.I., Ehab, D., 2017. Application of electrical resistivity for groundwater exploration in Wadi Rahaba, Shalateen, Egypt. NRIAG J. Astron. Geophys. 6, 201209. https://doi.org/10.1016/j.nrjag.2017.01.001

Mohamed, A.K., 2016. Application of DC resistivity method for groundwater investigation, case study at West Nile Delta, Egypt. Arab. J. Geosci. 9, 1-9. https://doi.org/10.1007/s12517-015-2054-6

Sathiyamoorthy, M., Ganesan, M., 2018. Delineation of Groundwater Potential and Recharge Zone Using Electrical Resistivity Method Around Veeranam Tank, Tamil Nadu, India. J. Inst. Eng. Ser. A 99, 637-645. https://doi.org/10.1007/s40030-018-0318-3 
Sihotang, J.W., Osvaldus, R., Munte, D.B.T., Priono, N., Mohamad, F., 2018. Aquifer Area Investigation Using Resistivity Method in Cikopomayak, West Java, $\begin{array}{llll}\text { Indonesia. } & \text { J. } & \text { Geofis. } & 16,\end{array}$ https://doi.org/10.36435/jgf.v16i3.375

Sulistyo, T., Abrar, A., 2017. Characterization of Thin Alluvial Bed Aquifers in Manggar River Balikpapan East Kalimantan Indonesia. JTT (Jurnal Teknol. Terpadu) 5, 54. https://doi.org/10.32487/jtt.v5i1.212

Suryadi, A., Putra, D.B.E., Kausarian, H., Prayitno, B.
Fahlepi, R., 2018. Groundwater exploration using Vertical Electrical Sounding (VES) Method at Toro Jaya, Langgam, Riau. J. Geosci. Eng. Environ. Technol. 3, 226. https://doi.org/10.24273/jgeet.2018.3.4.2226

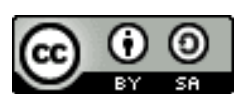

terms of the CC BY-SA License (http://creativecommons.org/licenses/by$\mathrm{sa} / 4.0 /)$. 